\title{
Evaluating the practice in Swedish school-age educare: Issues and contradictions
}

\author{
Helena Ackesjö ${ }^{1}$
}

\begin{abstract}
This article reports how teachers in Swedish school-age educare evaluate (SAEC) their practice. The study was conducted within a research- and development programme and is based on 47 teachers' written reflections about performing evaluations. The reflections have been analysed using various neo-institutional logics. The results indicate that the teachers' focus, regarding both the children and the practice, is directed differently when they are guided by different logics. When guided by the market logic, teachers focus on customer preferences and customer satisfaction. Guided by the professional logic, teachers focus the collective as well as the activities and the organisation around them. Guided by the bureaucratic and state logics, the teachers focus on the formal teaching, the individual child, and the school-age educare goal fulfilment. The results also show issues and contradictions concerning how to evaluate, what to evaluate, and when to evaluate. One possible claim is that the learning processes at the school-age educare are broad and complex, and thus difficult to "mould" to fit into evaluation schemes.
\end{abstract}

\section{Article History}

Received: 19 November 2021

Accepted: 18 January 2022

\section{Keywords}

School-age educare;

Evaluation; Neo-

institutional logics;

Teaching; Learning

\section{Introduction}

This article focuses on how teachers in the Swedish school-age educare (SAEC) evaluate their practice. The Swedish SAEC offers education and cares for children aged 6-12 years old, before and after school when their parents work or are engaged in studies. SAEC is an institution with more registered pupils than upper secondary school. Approximately $83 \%$ of all six to nine-year-olds attend SAEC (The government official investigations, SOU 2020, p. 34). Most countries offer childcare for school children, but the forms and organisation vary. Of the Nordic countries, only Sweden and Denmark employ higher educated staff in SAEC (Dahl, 2014; Pálsdóttir, 2012). Sweden is the only Nordic country with a specialised teacher education programme at the university level aimed at working in SAEC.

Historically, the Swedish SAEC has been based on a social pedagogical tradition, largely centred around a care-focused assignment combined with attention to children's fostering and development. This value system is based on the Nordic EduCare model, which emphasises humanistic aspects, such as wellbeing and social development, volunteering, play and rest (Gustafsson Nyckel, 2020; Johansson, 1984; Pálsdóttir, 2012). However, the mission of the SAEC has changed during the last decades. Since the late 1990s, the Ministry of Education is responsible for the SAEC in Sweden, and this programme is integrated into the school curricula. Since the beginning of the 2010s, more emphasis has been placed on teaching and learning in SAEC, which is related to the global discourse of knowledge efficiency and economic aspects of education (Andersson, 2013; Holmberg, 2018; Swedish School Inspectorate, 2010; 2018). This value system is based on an educational pedagogical tradition and can be demonstrated, for example, by the 2010 School Act and the 2016 revision of the current curriculum (Swedish National Agency for Education, 2019). In the curriculum, the SAEC teaching assignments have been clarified and highlighted in a specific chapter, in addition to the skills, children are supposed to develop during their time in the SAEC. In terms of ensuring both children's learning and quality instruction, the SAEC teaching must be evaluated. This article concerns how this evaluation is done. 


\section{Global Movements Indicating Change to a More Evaluation-Based Discourse}

It is safe to say that the changes in the Swedish SAEC mission and the shift towards an increased focus on knowledge efficiency and teaching can be understood in the light of global movements towards a learnification of education (Biesta, 2009). During the last 20 years, education has become subject to policy overload as a result of 'travelling educational policies' (Ball, 2017). Policy ideas change as they move around the world, which indicates that global and local policy logics are intertwined and entangled to such an extent that it can be difficult to determine where the developments begin or end (Pettersson et al., 2017). OECD is one of the major global policy influencers promoting national policy change through their reviews and recommendations. However, policy ideas change as they spread around the globe, and they take shape in different ways and for various reasons depending on the context. As a result, there will be compromises in balancing global policy with national interests, and historical and contextual traditions (Ackesjö \& Persson, 2019; Ball, 2017).

Processes such as decentralisation, deregulation, professional accountability, and marketisation (Nordin, 2012; Wahlström \& Sundberg, 2015) are ways to adjust and restructure national to global educational policy (Lindblad \& Popkewitz, 2004). This process has been called the Global Education Reform Movement (GERM) (Sahlberg, 2016), and it illustrates how countries have changed to a more evaluation-based discourse of governance with an emphasis on monitoring, inspection, and assessment. These changes have created a new evaluation-based educational landscape (Pettersson et al., 2017) and an efficiency discourse that puts results in focus. Biesta $(2011 ; 2017)$ calls this an era of measurements and warns that this development risks eroding the democratic dimensions of education and pushing professionals into a role of being standards-driven, evidence-based service providers (Biesta, 2017).

\section{Policy Changes at the National and Contextual Levels}

Behind the policy changes and reforms concerning the Swedish SAEC aimed at making it more about teaching and learning, there are arguments about increasing all pupils' achievement results in school. References to international knowledge assessments (TIMSS, PISA, PIRLS) motivate these investments and reforms. When the Swedish national results in PISA and other international knowledge assessments fell during the beginning of the 2000s, focus in the educational policy arguments shifted towards knowledge rationality and teaching, knowledge effectiveness, and goal achievement at all levels, namely, preschool, SAEC, and school ${ }^{1}$. The earlier focus on the intertwining of early childhood education and care in preschool and SAEC was transformed into policy discourses where goal-orientation were moved to the foreground (Ackesjö \& Persson, 2019). From a political standpoint, there are several reasons to invest in education for young children. These reasons are related to the financial and economic investment paradigm that emphasises the profitability of strengthening education for young children. It is widely held that young children's experiences of participating in early learning environments of high quality influence their chances in life (Heckman, 2004), and research findings suggest that participation in extra-curricular activities, such as the SAEC, is associated with improved academic performance (Guilmette et al., 2019). Increasing children's academic performance and positively influencing children's life chances are the main national political arguments behind the policy changes in SAEC, which come together in the revised curriculum with a clarified teaching mission and prescribed skills that children are supposed to develop. Given this background, the SAEC now has the task to contribute to children's development and learning at a general level (Ludvigsson \& Falkner, 2019). These movements illustrate the shift from the historical, social pedagogical tradition of the SAEC to the educational pedagogical tradition and its current focus on learnification.

Due to the global and national policy movements, the teachers in SAEC are positioned in a field of tension between tradition and new educational policy intentions. In the SAEC, children are to be offered meaningful free time before or after school, including care, rest, and creative activities. At the same time,

${ }^{1}$ The Swedish SAEC is included in the school curricula, and in this way becomes a part of the school system, even if parents, based on the family's needs, can choose whether or not their children participate in this educational programme. 
the SAEC shall be understood as an educational arena and should be focused on the prescribed skills that children are supposed to develop. Teachers try to navigate between these two different value systems (Ackesjö \& Haglund, 2021) as they adapt to the educational policy intentions presented in the revised curriculum, new school law descriptions, and a new teacher education programme (Ackesjö et al., 2020; Andersson, 2013; Gustafsson Nyckel, 2020; Haglund, 2015; 2016; Holmberg, 2018). The time that children spend in the SAEC shall include activities that support their school achievement and complement primary school teaching (Ludvigsson \& Falkner, 2019). As a result, children's time in the SAEC seems to have become increasingly institutionalised (Andersson, 2010; Saar et.al., 2012). The same trends are found in Norway and Denmark (Øksnes et al., 2014) as well as in countries outside the Nordic countries and Europe. The development has led to an increased focus on learnification of children's time outside the compulsory teaching, and how this can benefit both learning in general and children's school performance. The challenge is how teachers in the SAEC handle the dilemma between their teaching contributing to goal fulfilment and measurable results, at the same time as it creates meaningful and voluntary activities based on the children's interests and willingness (Ludvigsson \& Falkner, 2019).

As the assignment to teach has been added to the SAEC mission during the last years, it can be assumed that the concept of teaching is not yet well established. Research shows that due to the SAEC traditions, SAEC teachers seem to hesitate to absorb and implement the new way of thinking and rather use other concepts to describe what happens in the SAEC (Andersson, 2013; Närvänen \& Elvstrand, 2014; Saar et al., 2012). In doing so, teachers also mark the distance to the school ways of teaching and views of knowledge (Haglund, 2016).

It is still uncertain how teaching in the SAEC should and can be conducted. Neither the teaching practice nor the evaluation practice in SAEC is particularly researched. It also seems to be difficult to capture the teaching in the SAEC, since it is dominated by informal learning processes (Boström et al., 2015). The teaching is often embedded in everyday activities, and a common expression among teachers in SAEC is that they "try to catch the learning and teaching situations in the moment," which also means that it only involves the children who happen to be in place at that time. In addition, teaching in SAEC is also complicated by the fact that the SAEC is voluntary for children to participate in. It is therefore not possible to assume that the teaching in the SAEC reaches all, or even the majority, of the children enrolled. This complicates the teachers' teaching assignments (Ackesjö \& Haglund, 2021), but also complicates how to evaluate the teaching, if it should be evaluated, and how this can be done.

Teaching in SAEC, as in the compulsory school, is to be considered a goal-oriented process. Being a goal-oriented process, the teaching needs to be evaluated to ensure quality in the children's learning. However, since the concept of teaching in SAEC seems to be undefined, criteria for an evaluation in the SAEC are lacking, and research on this topic is minimal. Therefore, the aim of this study is to investigate how the evaluation of the teaching in the SAEC is conducted. The research question guiding this study is, which institutional logics are teachers guided by when evaluating the teaching in the SAEC?

\section{The Neo-Institutional Perspective}

Using a sociological neo-institutional perspective, this study involves an analysis of SAEC teachers' reflections about their work with evaluations. This perspective focuses on how the institutional order affects both actors and organisations and, conversely, how the actors' strategic actions, in turn, affect the institutional order (Eriksson-Zetterquist, 2009). Earlier institutional theoretical perspectives placed greater emphasis on institutionalisation processes at an organisational and societal level, which meant the actor perspective fell into the background and the actors were constructed as passive (DiMaggio \& Powell, 1991). In the present study, the actors (the teachers) and their stories about their evaluation practice are placed at the centre.

The concept of the institution has been defined in many different ways based on what is considered to be in focus. In this study, the institution is defined as a... "more-or-less taken-for-granted repetitive social behaviour that is underpinned by normative systems and cognitive understandings that give 
meaning to social exchange and thus enable self-reproducing social order" (Greenwood et al., 2008, p. 4$5)$.

Institutions are built by normative and regulatory systems which Scott (2014) defines as the institution's pillars. These pillars make sense and are produced and reproduced in different ways by those working within the institution according to the norms, values and rules on which the institution is based (Friedland \& Alford, 1991; Thornton, 2004). Thereby, these pillars form the basis and create stability and meaning in the institutional order (Scott, 2014).

The concept of logics has become central to this theory, and logics have been defined as the guiding principle. Actors in an institution meet different and varying requirements, and to deal with these, the actors (consciously or unconsciously) are guided by different logics (Friedland \& Alford, 1991). Logics are about rules of action, interpretation, and interaction (Thornton \& Ocasio, 1999) and emphasise the importance of social context. Attention to the societal level of institutional orders is necessary to understand individual and organisational behaviour. Logics shape the behaviours of social actors (Friedland \& Alford, 1991) and provide conventions for deciding which issues may be important enough to be worth solving. This theory provides tools for analysing how individuals and organisations are affected in an interinstitutional system, such as the institutional order of family, state, market and profession (Thornton et al., 2012). Friedland and Alford (1991) have developed five logics; market, bureaucratic state, democracy, family and Christianity. Thornton (2004) then developed these into six logics; market, state, profession, company, family, and religion. Of particular interest in this paper are the market logic, the professional logic, and the bureaucratic state logic. All these logics are contained under the umbrella of institutional logic.

Within the market logic, free and unregulated competition with consumer preferences and choice are what determine success (Friedson, 2001). This logic has competition and individualisation as means and goals, and schools are seen as parts of a market that competes with students, teacher resources, and academic results. Within this logic, school and education are viewed through a market lens, and a customer-oriented view of the students is visible. It is possible for teachers to regard children and parents as customers, which in turn means that children and parents are given power and influence over pedagogical decisions. The customer or consumer preferences govern what services are available (Fredriksson, 2010). Discourses about efficiency, competition and performance culture may, however, stand in opposition to a profession's freedom of action and its professionalism, as the professionals can take on a controlled, service-oriented role in this market (Lundström \& Parding, 2011).

Within the professional logic, professionals rely on abstract knowledge to conduct their practice solely or in partnership with others of the same profession. Within the professional logic, it is possible to take control over the content and organisation of the work (Goodrick \& Reay, 2011) as the profession "monitors" its professional knowledge both within the profession and vis-à-vis other professions (Brante, 2014; Friedson, 2001). The control is based on teachers' knowledge, judgment, independence, and the pursuit of a certain autonomy springing from jurisdiction. Professionals practise within a framework with a specific scope, norms, and values in their field of work (Brante, 2014). This means that this logic emphasises a bottom-up perspective, as the professionals' experiences and autonomy, as well as their unique knowledge, guide them (Brante, 2014; Friedson, 2001).

Within the bureaucratic state logic, the government takes responsibility for professional work as opposed to ratifying professional desires. Hence, professionals are seen as employees of the state, and the state controls the credentials for professional practice and the organisation of their work (Goodrick \& Reay, 2011). Focus in the state logic is equivalent education and how the pupils can contribute to the development of society, but it also includes values such as democratic principles, political ideology, welfare, and power (Thornton, 2004) which guide the teachers' work. Teachers' work is politically steered through regulations and instructions stemming from the state control as well as centralised and formalised to ensure standardisation within the institution (Friedson, 2001). The logic implies loyalty to the regulations rather than to the professions (Fredriksson, 2010). This means that this logic emphasises a top-down perspective, as results and documentation shall be delivered "upwards" according to a pre-determined supply chain. 
The logics used in the present study are illustrated in Figure 1 below.

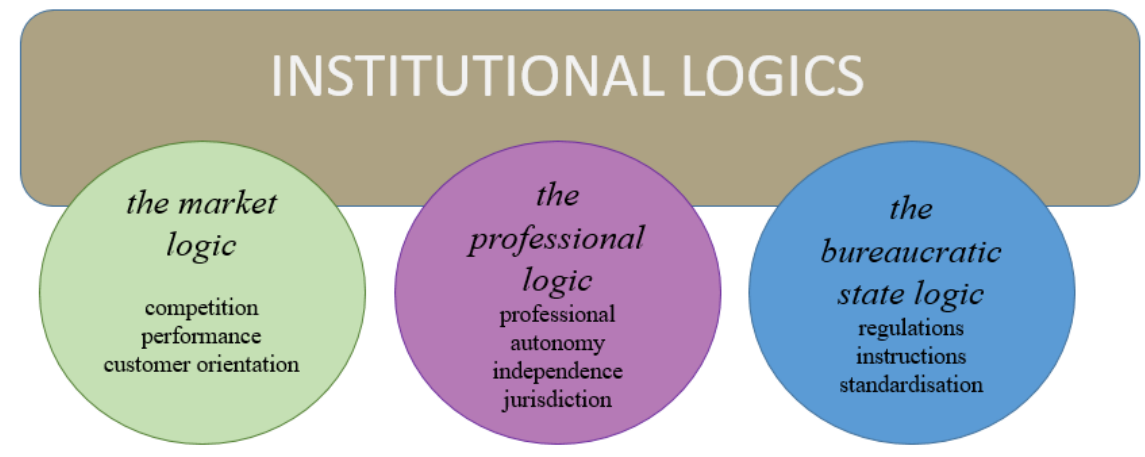

Figure 1. Illustration of the logics used in this study.

Logics are one way of understanding the human organisation, but they do not constitute a direct description of reality. Instead, they are abstract generalisations, refined and modelled in a way to appear precise and contrasting. However, logics can create contradictions and/or be competitive; when guided by logics, professionals are often forced to prioritise. Professionals are likely to identify more strongly with one or more logic in their field of work than with others (Ackesjö, 2021). Logics can also be hybrid, as the professionals are guided by several different logics at the same time in order to maintain the legitimacy of their actions, but also to challenge the institutional order (Scott, 2008). Contradictions within an institution, and the different value bases of these logics, contribute to making different logics predominate in different ways depending on situations and actions as this paper will show.

\section{Method}

This study was conducted within the research and development programme entitled SAEC's pedagogical assignment ${ }^{2}$. This was a three-year programme which included both SAEC teachers, principals and heads of educational administrations in 31 schools in four different municipalities/districts. The aim of the development part of the programme was to a) increase and develop knowledge about how the SAEC's activities and collaboration with the compulsory school can contribute to good conditions for students' learning, and b) increase knowledge about the principal's responsibility to lead and manage the SAEC. Out from this focus, the aim of the research part of the programme was formulated to describe and define how teaching in the SAEC can be conducted and how the concept of teaching can be understood in relation to the SAEC.

The research and development parts of the programme were intertwined and conducted in close collaboration with the involved SAEC teachers. The work can be described as participant-oriented and was based on Ellström (2010) model on how participant-oriented research becomes relevant to the participants, at the same time as it can contribute to a build-up of research-based knowledge and theory formation and provide a basis for and support development work in the participating schools. Ellström calls it interconnected learning cycles, which consist of a practice system and a research system. Researchers, teachers and principals define problems in a joint process, carry out different activities and jointly try to interpret and understand the results and effects that arise (Ellström, 2010). One such defined problem was how to plan, conduct and evaluate teaching in the SAEC. With support from the researchers, the participating teachers focused on developing their teaching at their schools for a number of weeks until the next meeting in the programme.

As the program lasted for three years (2019-2022), the number of participating teachers varied. When data for this study was gathered, 73 SAEC teachers were involved in the programme. The work experience within the teacher group ranged from a few months (newly graduated SAEC teachers) to several decades

\footnotetext{
${ }^{2}$ A three-year research and development project funded by IFOUS (Innovation, research and development in school and preschool) $2019-2022$.
} 
(SAEC educators with a degree from the 1980s). In the present paper, all respondents are called SAEC teachers, regardless of educational background. The study conforms to the Swedish Research Council ethical principles (2017). The respondents were informed at the start of the research and development programme about the purpose of the research, about the research was going to be published, that confidentiality was guaranteed and that they may refrain from participating.

Since this research and development programme started just before the start of the COVID-19 pandemic, only two physical meetings with the participants could be conducted. The rest of the meetings (3-4 per year) were digital. The data used in this study consists of written reflections upon the question: How do you evaluate learning in the SAEC? To collect the written reflections in a way where confidentiality was guaranteed, a web-based system was constructed in the Sunet Survey program. By logging in and writing their reflections, teachers gave their consent. The questions were e-mailed to all participants along with an individual login to the system, which was used to enter and write their reflections. After a few reminders, reflections from 47 of the participating teachers were received.

The collected empirical material was handled with confidentiality according to the Swedish Research Council ethical principles (2017). Even though the respondents in this study were predetermined, and the questions were e-mailed to the respondents, I did not know who answered the questions. The data have been stored on the university server and only made available to the researchers in the project through password-protected computers. The raw material was stored digitally and password-protected in the digital system Sunet Survey. All research data has been handled in accordance with the university's guidelines for data management and the GDPS ordinance. Ethical considerations have been present throughout the research process as it has been presented honestly, openly, fairly, completely and in an objective way.

The dataset was analysed as inspired by a combination of what Reay and Jones (2016) call pattern inducing and pattern matching. First, the empirical data was carefully read through. All individual written reflections were given a number representing the individual teachers (marked with 1-47). Then, with an inductive technique, empirical patterns were identified in the raw data using a bottom-up process (Reay \& Jones, 2016). At this stage, patterns such as formal/informal evaluations, evaluation of activities and/or teaching and goal-related evaluations were induced. Thereafter, these identified patterns were matched to the predefined logics described in the theoretical section. For example, the formal/informal evaluations were matched to the market logic based on the focus on customer satisfaction. Thereby, the content in the text segments could be analysed and meanings could be revealed in each logic. In addition, nuances in the local practices can be highlighted, and the results can be visualised (Reay \& Jones, 2016) as in the following results section.

Finally, some considerations about this study's validity and reliability. Internal validity is concerned about what the researcher can really say something about based on their data. The credibility of the interpretations is all about the researcher's craftsmanship, about critically relating to his interpretations in order to avoid distorting the results (Kvale, 1997). The validity is thus dependent on whether the statements presented hold the test against other alternative statements. The validity in this study has been strengthened by reporting the analysis process as carefully as possible. Elements from the theoretical base and previous research also reappear in the results analysis and discussion, which helps to highlight the new knowledge that has been constructed. External validity is concerned about how the results can be generalized to other cases or situations (Schofield, 1993). The aim of this study has been to offer as clear and detailed descriptions as possible so that the reader can determine whether the results can be generalized. I humbly face the fact that the empirical data does not provide a comprehensive picture of evaluation in the SAEC. Nevertheless, it can be argued that the statements described in the study are by no means unique; the reader may find recognition in parts of the data and the results. The selected excerpts have been discussed at a more general and theoretical level, which contributes to that the examples can gain value even outside the described national context. 


\section{Findings}

The written reflections that have been collected for this study indicate that evaluations do not always take place, since teachers seem to find it difficult to evaluate what is going on in the SAEC. These difficulties may be related to the SAEC's recurring situation-driven informal learning and experience-based activities. There seems to be an ambiguity in how learning at the SAEC can be captured, what it is that actually should be evaluated when this evaluation should take place and how:

We find it very difficult to evaluate the learning at the SAEC. Should we even evaluate? When should we evaluate? (21)

We agree that informal learning takes place all the time at the SAEC, but it is more difficult to evaluate than formal learning since the goal is not as clear. (35).

In addition to this, the teachers also seem to be limited in their professional assignment. They often do not have time set aside to evaluate, but rather to look ahead and plan for the coming week. These reflections go in line with previous research (Ackesjö \& Haglund, 2021; Boström et al., 2015;) that has shown that the teaching in the SAEC often is not organised, but rather embedded in the everyday life and therefore rather hard to both plan and evaluate.

However, even if there seems to be ambiguity and some confusion about how and what to evaluate, the teachers also describe how they proceed with the evaluation work. The following sections will illustrate the logics these teachers seem to be guided by when evaluating the teaching in the SAEC.

\section{The Market Logic - Customer Satisfaction}

One common way to evaluate is to ask the children what they think about the activities in the SAEC. What is evaluated is above all the children's satisfaction and engagement, but not necessarily what they have learned or what development the teaching has contributed to.

In the written reflections, mainly two forms of evaluation appear, informal and formal. A common informal way to evaluate informally is to let the children show whether they liked or disliked an activity with thumbs up/thumbs down:

We usually do "thumbs up" and "thumbs down" after the activity as we talk about the activity. (44)

Sometimes, for example, if you have been in the sports hall, you can do a quick check with "thumbs up or down".

Then you'll get the children's opinions. (41)

We ask the children after each activity, listen to them and their views and wishes. (38)

A more formal way of evaluating together with the children is to let them grade the activities and/or fill in questionnaires:

We usually do simple evaluations together with the children after the activities. They use post-it notes and may give stars or similar things based on certain questions. (31)

Every week we have a children's council with the whole group. Sometimes we evaluate our activities with them. We have also had small student councils on Fridays with two children from each class. ... They have written [aspects of the SAEC activities] in stars that we put up in our hall for all children and parents to see. (27)

The above-described evaluation methods are focused on children's opinions, views, and wishes. Doing an evaluation seems to be about getting information about whether the children thought the activity was fun; a five-star activity is a really fun activity. Embedded in this evaluation work appears to be an underlying ambition to make sure that children are satisfied and also to illustrate performatively and visually to outsiders (parents, other teachers, school management, etc.) what is going on at the SAEC.

These empirical examples illustrate how teachers are guided by the market logic which holds consumer preferences and choice (Friedson, 2001) in the centre. When guided by this logic, teachers hold the process and the customer (child) in focus. If the customer is pleased, all is well. The evaluation can be seen as a way for the teachers to evaluate their contribution in relation to the children's satisfaction and how the children experienced their contribution. The aim here is not to evaluate if any learning took place or to evaluate teaching towards set goals; it is not even certain that the activities have any clear intentions 
Evaluating the practice in Swedish school-age educare...

or learning goals to begin with. Rather, the focus is customer satisfaction.

In addition, when teachers are guided by the market logic, it may be possible to identify the historical, social pedagogic tradition of SAEC, a value system which emphasises aspects such as freedom, well-being, and children's play (Gustafsson Nyckel, 2020; Johansson, 1984; Pálsdóttir,, 2012). Within this logic, individualisation and the individual's free choices are seen as means and goals. Nowadays, the SAEC and the school are parts of a market that competes with resources. Hence, through a market lens, a satisfied customer is preferred.

\section{The Professional Logic - Activities, Not Teaching}

Another way to evaluate is through collegial reflections within the work teams. In these conversations, the teachers evaluate the activities that have been carried out in terms of how things worked out:

In our work teams, we present and discuss what activities we do in our various departments. (31)

During our weekly planning meetings, we evaluate the past week and the activities we have done. (43)

We evaluate when we have our planning meetings. We highlight what is going well and what we can/could develop/have done differently in the different activities. (39)

The focus of these evaluations seems to be to make a situation assessment over the past week. The colleagues give each other feedback on the various initiatives and discuss how the daily work can be built upon. The evaluation of the week thus forms the basis for discussions on how to develop and plan next week's work together.

Notable is how the teachers talk about what is being done during the week. The focus in the evaluation does not seem to be about making the children's learning visible or directing the upcoming activities towards set goals, but rather appears to be about the practical organisation and informing each other about various completed activities and what went well. That the focus is on how teachers themselves have carried out the activities rather than on children's learning is indicated by the use of 'we', what we can/could develop/have done differently, what activities we do and activities we have done.

These excerpts can be related to how teachers are guided by professional logic. Guided by this logic, teachers rely on their traditional knowledge about how to conduct their practice with others of the same profession. This logic allows them to take control over the content and organisation of the work (Goodrick \& Reay, 2011) based on the pursuit of a certain autonomy. This is implied with the way in which the teachers most frequently describe their work as activities and not teaching, which lies partly embedded within the norms and values (Friedland \& Alford, 1991) in their institutional, social pedagogical tradition and culture in the SAEC. This is also in line with previous research that shows that SAEC teachers' hesitation about the teaching concept is rooted in the traditions and willingness to use other concepts to describe what happens in the SAEC (see Andersson 2013; Närvänen \& Elvstrand, 2014; Saar et.al., 2012). This may also be a way to set some distance from the school's teaching and views of knowledge (see Haglund, 2016). SAEC teachers rather seem to use other words based on their specific norms and values from their field of work in describing how they evaluate what happens in the SAEC. In line with the SAEC traditions, norms, and values, they also reflect upon and evaluate practical and organisational aspects of the activities rather than the learning aspects of their teaching.

\section{The Bureaucratic State Logic - Goal-Focused Quality Management}

A third way to evaluate is carried out in relation to the set national goals for the SAEC. These evaluations seem also preferably to be made as collegial reflections within the work teams:

Every week the work team evaluates how we have completed our work before making a new plan. We consider the children's participation and if we saw any visible learning as well as what we can develop and move forward with. We work according to a year cycle of pedagogical plans, so that we can ensure that we cover the skills [the children ought to develop at SAEC] and the Central content [which is prescribed] in the curriculum. (20)

In the evaluations, previous evaluations carried out together with the children can also be included: 
We evaluate the learning process through a clear purpose and set goals. We also document the learning through written notes. We inform the children about the purpose and goals of the activity before the start and tie the knot after the activity by asking what they have done/trained. We also have dialogues with the children during the activity to make the learning visible to the children in order to increase the learning. We then use all this as a basis for assessing learning at the end of each selected focus area. (40)

These reflections indicate how teachers are guided by the bureaucratic state logic, which stresses how the state controls the credentials for professional practice and the organisation of their work (Goodrick \& Reay, 2011). Teachers' work is politically steered through regulations and instructions to ensure standardisation and equivalent education within the institution (Friedson, 2001) and the excerpts show how professional desires do not seem to be in focus, rather the fulfilment of the state's national goals set for the SAEC. The teachers describe how they draw guidance and direction from the national governing policy documents when they plan their teaching. It is towards these set goals that the SAEC teaching is evaluated. This indicates goal-focused quality management of the teaching in the SAEC, based on a kind of technical rationality in line with the bureaucratic state logic. The focus in teachers' descriptions, guided by this logic, seems to be centred on children's learning, which is in contrast to the focus on activities when guided by professional logic.

The teachers seem to have developed templates for the plans and the evaluations, templates that are based on the set national goals for the SAEC. This implies that templates and written evaluation documents can be made necessary in order to visualise the learning that takes place at the SAEC. The visualisation seems to be directed both towards the children in order for them to be able to become aware of and increase their learning, and towards the work team in order to illustrate what needs to be developed and further worked on. In addition, guided by the bureaucratic state logic, the templates and visualisation emphasise a top-down perspective, as the results and documentation shall be rendered, as well as the teachers' loyalty, to the state regulations (Fredriksson, 2010).

The analysis shows that the teachers are guided by different logics while performing evaluations in the SAEC. Interesting to note is that the question the teachers were asked to answer was, How do you evaluate learning in the $S A E C$ ?, but very few answers contained reflections about evaluating learning. Instead, the answers focused on evaluating teaching or organisation (or not evaluating at all). The results are illustrated in Figure 2 below.

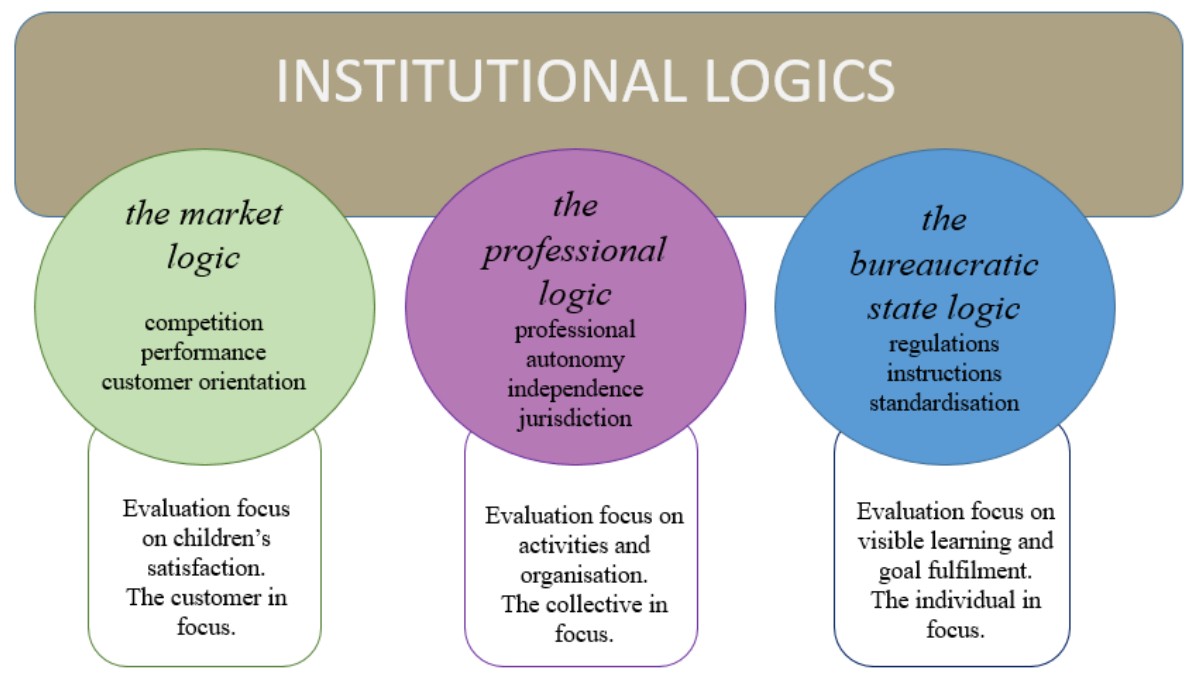

Figure 2. Illustration of the results.

The results show a variation in how the evaluations are done and what they focus on. Guided by the market logic, customer preferences and the satisfied customer (child/parent) are in focus. Guided by the professional logic, the collective, the group as well as the activities (perhaps based on the SAEC social pedagogical traditions) and the organisation around these are in focus. Guided by the bureaucratic state logic, 
the formal teaching, the individual child and the learning and development of certain prescribed skills, the child's visible learning and the SAEC's goal fulfilment are in focus.

Thus, the results indicate that teachers' focus, regarding both the children and the practice, is directed differently when they are guided by the different logics. Different logics lead to different evaluation practices since professionals act differently depending on which logic they are predominantly guided by (Friedson, 2001; Goodrick \& Reay, 2011; Thornton, 2004). This may not be an issue if the teachers are aware that different logics put different aspects in focus.

Different logics coexist, and some logics dominate others (Ackesjö, 2021; Friedson, 2001; Goodrick \& Reay, 2011; Thornton, 2004). It is safe to say that the SAEC teachers are guided by a coexisting mix of logics, which all are based on different values. Logics express and manifest themselves differently and leave different traces in the institution (Thornton, 2004). Teachers' actions are responses to the state's demands, but also to their tradition and culture in the SAEC, at the same time as their actions also are "responses" which produce new conditions. In other words, teachers are institutional actors and contribute to creating institutional logics at the same time as they are created by them (see Ackesjö, 2021).

The analysis also shows that GERM, the Global Education Reform Movement (Sahlberg, 2016) and its worldwide movement of restructuring education, does not dominate the SAEC. Even if some of the teachers, when guided by the bureaucratic state logic, put formal teaching, the child's visible learning, and evaluation of the SAEC goal fulfilment in focus, this does not dominate the teachers' collective descriptions of how they evaluate. Even if the SAEC at the policy level is positioned in an evaluation-based educational landscape where monitoring, assessment, efficiency, and results are central aspects (Biesta, 2011; Pettersson et al., 2017), this seemingly has not changed the practice in the SAEC in a radical way. It still appears to be important to ask for children's opinions, to focus on making children and parents happy and satisfied, to use democratic ways of working involving children, and to maintain the SAEC social pedagogical traditions.

\section{Pedagogical Implications - Issues and Contradictions}

The results show that there seems to be ambiguity in how learning at the SAEC can be captured in order to be evaluated, what it is that actually should be evaluated, and when this evaluation should take place and how. The teachers are also apparently limited in time to be able to evaluate. There are no nationally formulated standards to be used in evaluation in SAEC. There are no formulated knowledge requirements for children in the SAEC, only the skills the children should be given the opportunity to develop and these are not limited in time, but apply during all the years the children are enrolled in SAEC. This may explain why teachers ask questions about what is to be evaluated and when evaluations should be done. This may also explain why teachers are guided by several different (and maybe contradictory) logics when evaluating. But most of all, these results highlight the need for developing professional knowledge about how to evaluate formal and informal learning at the SAEC.

In addition, there are some notable issues to discuss. For instance, what happens if the SAEC is mainly regarded as a quasi-market where children are customers with the right to choose whether or not they want to be present or not? Based on the market logic, the children thus gain power over the teachers; the focus is to make them satisfied and not change the school or SAEC. If so, there may be a risk that the teachers mainly adapt to the children's wishes, and they downplay quality and professionalism in order to satisfy them (see Lundahl et al., 2014). One risk identified in the results is that customer preferences may govern how the teaching is conducted (see Fredriksson, 2010) and what the teaching should focus on at the SAEC, which could lead to the teachers becoming more service-oriented personnel than professional teachers (see Lundström \& Parding, 2011).

Another issue to discuss is the possible need for national evaluation models in the SAEC. Based on the state and bureaucratic logics, it would be natural to consider increased national control of what is to be evaluated and how this is to be done to ensure higher quality in the SAEC. However, one pitfall with national evaluation models is that they tend to become normative glasses, through which all activities will 
be filtered. Thus, there would be the risk that both the collegial reflections and the importance of the children's experience, satisfaction, and engagement would be lost if national and normative evaluation models directed towards nationally set standards were implemented. Another risk is if the national evaluation models determine the content of the teaching. Within a bureaucratic state logic, the templates and a top-down perspective with a focus on delivering results (Fredriksson, 2010) are a natural part. But would this benefit the SAEC?

The results highlight contradictions concerning evaluations in the SAEC. It is safe to say that the teachers in SAEC are positioned in a field of tension between tradition and new educational policy intentions. The political reforms have converted the SAEC into a practice that is goal-oriented and voluntary at the same time (Holmberg, 2018). The teachers must conduct a school law-regulated education with goal-directed and planned teaching, while at the same time also offering meaningful free time for the children based on their interests and needs. The practice must be professionally managed, but at the same time be open to the children's interests and suggestions. It is still voluntary for children to participate in the SAEC program. As previous research has shown (Ackesjö et.al., 2020; Ackesjö \& Haglund, 2021; Andersson, 2013; Gustavsson Nyckel, 2000; Haglund, 2015; 2016), the teachers try to navigate between these two different value systems as they adapt to the educational policy intentions presented in the revised curriculum, new school law descriptions, and a new teacher education programme. This may explain the ambiguity that teachers expressed in, for example, what concepts to use (activities or teaching?) and what and when to evaluate.

We may need to think differently about evaluation in the SAEC. It could be possible to claim that the learning process that is staged and made visible in the SAEC is broad and complex and cannot be "moulded" to fit into evaluation schemes. At the SAEC, it may not be enough to have the nationally prescribed central content and abilities as the norm for the evaluation. The child at the SAEC develops a number of abilities and skills, both those that are teacher-steered, goal-directed and those that are selfinitiated. These may be hard to evaluate. At the SAEC, learning often takes place at the moment, in different rooms, and in various social contexts with or without teachers present or engaged. These learning processes are sometimes both difficult to plan in advance and difficult to capture in an evaluation. Thus, evaluation may take on a different meaning in the SAEC, a meaning that cannot be compared to the goal-rational model that dominates the view of the evaluation-based education that, for example, GERM in the era of measurement proposes.

The results show a variation in how evaluations are done in SAEC and what they focus on, but also that teachers' focus regarding both the children and the practice is directed differently when they are guided by different logics. This creates a variation of evaluation practices with different focus and intentions. Thus, the implications for practice have the urge to continue discussing what evaluation in the SAEC is, how it should be carried out and what should be evaluated. If the SAEC is to be expected to contribute to children's development and learning, these issues must be constantly present and discussed in all work teams.

\section{Declarations}

Editorial Acknowledgement: The editorial process of this article was carried out by Dr. Mine Gol-Guven.

Acknowledgements: I acknowledge and appreciate the participants' engagement, time and contribution to this study.

Authors' contributions: This is the sole work of the author.

Competing interests: No competing interests.

Funding: The study is part of a research and development program financed by IFOUS (Innovation, research and development in school and preschool) 2019-2022.

\section{References}

Ackesjö, H. \& Haglund, B. (2021). Fritidspedagogisk undervisning: En fråga om intentionalitet, situationsstyrning och inbäddning. [Teaching in the schol-age educare: teaching: A question of intentionality, situation management and embedding]. Utbildning 
Evaluating the practice in Swedish school-age educare...

\section{$\mathcal{E}$ Lärande, 15(1), 69-87. http://du.diva-portal.org/smash/get/diva2:1539113/FULLTEXT01.pdf}

Ackesjö, H. \& Persson, S. (2019). The schoolarisation of the preschool class - policy discourses and educational restructuring in Sweden. Nordic Journal of Studies in Educational Policy, 5(2), 127-136. https://doi.org/10.1080/20020317.2019.1642082

Ackesjö, H. (2021). Early assessments in the Swedish preschool class - coexisting logics. Cepra-Striben, $27,38-49$. https://doi.org/10.17896/UCN.cepra.n27.417

Ackesjö, H., Lindqvist, P. \& Nordänger, U. K. (2020). De första åren i yrket - nyutexaminerade lärares upplevelser av en ny yrkesroll. [The first years in the profession - newly graduated teachers' experiences of a new professional role.] In B. Haglund, J. Gustafsson Nyckel \& K. Lager (Eds). Fritidshemmets pedagogik i en ny tid (pp.101-117). Gleerups.

Andersson, B. (2010) Introducing assessment into Swedish leisure-time centres - pedagogues' attitudes and practices. Education Inquiry, 1(3), 197-209. https://doi.org/10.3402/edui.v1i3.21942

Andersson, B. (2013). Nya fritidspedagoger - i spänningsfältet mellan tradition och nya styrformer [New leisure educators - in the field of tension between tradition and new forms of government.] [Doctorate thesis]. University of Umeå.

Ball, S. J. (2017). The education debate (3 ed.). Policy Press.

Biesta, G. (2009). Good education in an age of measurement: On the need to reconnect with the question of purpose in education. Educational Assessment Evaluation and Accountability, 21(1), 33-46. https://doi.org/10.1007/s11092-008-9064-9

Biesta, G. (2011). God utbildning i mätningarnas tidevarv. [Good education in the era of measurement.] Liber.

Biesta, G. (2017). Education, measurement and the professions: Reclaiming a space for democratic professionality in education, Educational Philosophy and Theory, 49(4), 315-330. https://doi.org/10.1080/00131857.2015.1048665

Boström, L., Hörnell, A. \& Frykland, M. (2015). Learning environments at leisure-time centres in Sweden: A comprehensive survey of staff perceptions. International Journal for Research on Extended Education, 3(1), 5-23. http://dx.doi.org/10.3224/ijree.v3i1.19578

Brante, T. (2014). Den professionella logiken: Hur vetenskap och praktik förenas i det moderna kunskapssamhället. [The professional logic: How science and practice are combined in the modern knowledge society.] Liber.

Dahl, M. (2014). Fritidspedagogers handlingsrepertoar. Pedagogiskt arbete med barns olika relationer [Leisure educators' action repertoire. Educational work with children's different relationships.] [Doctorate thesis]. Linnaeus University.

DiMaggio, P. L., \& Powell, W.W. (1991). Introduction. In W. Powell \& P. DiMaggio (Eds.), The new institutionalism in organizational analysis (pp. 1-38). The University of Chicago Press.

Ellström, P.-E. (2010). Helix årsrapport. [Helix annual report.] Linköpings Universitet.

Eriksson-Zetterquist, U. (2009). Institutionell teori-idéer, moden, förändring. [Institutional theory - ideas, modes, change.] Liber.

Fredriksson, A. (2010). Marknaden och lärarna. Hur organiseringen av skolan påverkar lärares offentliga tjänstemannaskap [The market and the teachers. How the organization of the school affects teachers' public service.] [Doctorate thesis]. Göteborg University.

Friedland, R., \& Alford, R. R. (1991). Bringing society back in: Symbols, practices and institutional contradictions. In P. J. Di Maggio \& W. W. Powell (Eds.), The new institutionalism in organizational analysis (pp. 232-263). University of Chicago Press.

Friedson, E. (2001). Professionalism the third logic. Polity Press.

Goodrick, E. \& Reay, T. (2011). Constellations of institutional logics: Changes in the professional work of pharmacists. Work and Occupations, 38(3), 372-416. https://doi.org/10.1177/0730888411406824

Governments official investigations, SOU 2020:34. Stärkt kvalitet och likvärdighet i fritidshem och pedagogisk omsorg. [Strengthened quality and equivalence in school-age educare and educational care.] Ministry of Education.

Greenwood, R., Oliver, C., Sahlin. K., \& Suddaby, R. (2008). Introduction. In R. Greenwood., C. Oliver., K. Sahlin \& R. Suddaby (Eds.), The SAGE handbook of organizational institutionalism (pp. 1-46). SAGE.

Guilmette, M., Mulvihill, K., Villemaire-Krajden, R., \& Barker, E. T. (2019). Past and present participation in extracurricular activities is associated with adaptive self-regulation of goals, academic success, and emotional wellbeing among university students. Learning and Individual Differences, 73, 8-15. https://doi.org/10.1016/j.lindif.2019.04.006

Gustafsson Nyckel, J. (2020). Vägen mot det undervisande fritidshemmet. [The road towards the teaching school-age educare.] In B. Haglund, J. Gustafsson Nyckel \& K. Lager (Eds.) Fritidshemmets pedagogik i en ny tid (p. 59-87). Gleerups.

Haglund, B. (2015). Everyday practice at the Sunflower: The staff's representations and governing strategies as contributions to the order of discourse. Education Inquiry, 6(2), 209-22. https://doi.org/10.3402/edui.v6.25957

Haglund, B. (2016). Fritidshemmets vardagspraktik i ett nytt diskursivt landskap. [The school-age educare's everyday practice in a new discursive landscape.] Educare, 1, 64-85.

Heckman, J.J. (2004). Invest in the very young. In R.E. Tremblay., R.G. Barr., R.DeV. Peters. (Eds.) Encyclopedia on Early Childhood Development [online]. Centre of Excellence for Early Childhood Development; 2004:1-2. 
Helena ACKESJÖ

http://www.childencyclopedia.com/documents/HeckmanANGxp.pdf.

Holmberg, L. (2018). Konsten att producera lärande demokrater [The art of producing learning democrats.] [Doctorate thesis]. Stockholm University.

Johansson, I. (1984). Fritidspedagog på fritidshem: En yrkesgrupps syn på sitt arbete [Leisure educator at a leisure time center: A professional group's view of their work.] [Doctorate thesis]. Göteborg University.

Kvale, S. (1997). Den kvalitativa forskningsintervjun. [The qualitative research interview] Studentlitteratur.

Lindblad, S., \& Popkewitz, T. S. (Eds.). (2004). Educational restructuring. International perspectives on travelling policies. Information Age Publishing.

Ludvigsson, A. \& Falkner, C. (2019). Fritidshem - ett gränsland i utbildningslandskapet: Lärare i fritidshems institutionella identitet. [School-age educare - a borderland in the educational landscape: SAEC teachers' institutional identity.] Nordisk tidsskrift for pedagogikk og kritikk, 5, 13-26. https://doi.org/10.23865/ntpk.v5.1181

Lundahl, L., Erixon Arreman, I., Holm, A. \& Lundström, U. (Eds.) (2014). Gymnasiet som marknad. [Upper secondary school as a market.] Boréa.

Lundström, U. \& Parding, K. (2011). Lärares upplevelser av friskolereformen - effekter av marknadiseringen av den svenska gymnasieskolan. [Teachers' experiences of the independent school reform - effects of the marketing of the Swedish upper secondary school.] Arbetsmarknad \& Arbetsliv, 17(4), 59-77.

Närvänen, A-L. \& Elvstrand, H. (2014). På väg att (om)skapa fritidshemskulturer. Om visioner, gränsdragningar och identitetsarbete. [On the way to (re)create leisure center cultures. About visions, demarcations and identity work.] Barn. Forskning om barn og barndom $i$ Norden, 32(3), 9-25. https://doi.org/10.5324/barn.v33i3.3498

Nordin, A. (2012). Kunskapens politik - en studie av kunskapsdiskurser i svensk och europeisk utbildningspolicy [The policy of knowledge a study of knowledge discourses in Swedish and European education policy.] [Doctorate thesis]. Linnaeus University.

Øksnes, M., Knutas, A., Ludvigsson, A., Falkner, C. \& Kjaer, B. (2014). Lekens rolle i skandinaviske skolefritidsordninger og fritidshjem. [The role of play in Scandinavian leisure time centers.] Barn. Forskning om barn og barndom i Norden, 32(3), 107123. https://doi.org/10.5324/barn.v33i3.3504

Pálsdóttir, K. (2012). Care, learning and leisure: The organisational identity of after-school centres for six-to nine-year old children in Reykjavík [Doctorate thesis]. University of Iceland.

Pettersson, D., Prøitz, T. S., \& Forsberg, E. (2017). From role models to nations in need of advice: Norway and Sweden under the OECD's magnifying glass. Journal of Education Policy, 32(6), 721-744. https://doi.org/10.1080/02680939.2017.1301557

Reay, T. \& Jones, C. (2016). Qualitatively capturing institutional logics. Strategic Organization, 14(4), 441-454. https://doi.org/10.1177/1476127015589981

Saar, T., Löfdahl, A. \& Hjalmarsson, M. (2012). Kunskapsmöjligheter i svenska fritidshem. [Knowledge opportunities in Swedish leisure time centers.] I Nordisk Barnehageforskning, 5(3). 1-13. https://doi.org/10.7577/nbf.315

Sahlberg, P. (2016). The global educational reform movement and its impact on schooling. In Mundy, K., Green, A., Lingard, B., \& Verger, A. (Eds.), The handbook of global education policy (pp. 128-144). John Wiley \& Sons.

Schofield, J.W. (1993). Increasing the generalizability of qualitative research. In M. Hammersley (Ed.), Social research: Philosophy, politics and practice (pp. 200-225). Sage Publications.

Scott, W. (2008). Approaching adulthood: The maturing of institutional theory. Theory and Society, 37(5), 427-442. https://doi.org/10.1007/s11186-008-9067-z

Scott, W. (2014). Institutions and organizations: Ideas, interests and identities (4th ed.). SAGE Publications.

Swedish National Agency for Education. (2019). Läroplan för grundskolan samt för förskoleklassen och fritidshemmet (Lgr11). [Curriculum for compulsory school and for the preschool class and school-age educare (Lgr11).] Ministry of Education. https://www.skolverket.se/undervisning/grundskolan/laroplan-och-kursplaner-for-grundskolan/laroplan-lgr11-forgrundskolan-samt-for-forskoleklassen-och-fritidshemmet

Swedish Research Council. (2017). God forskningssed. [Good research practice.] Vetenskapsrådet. https://www.vr.se/analys/rapporter/vara-rapporter/2017-08-29-god-forskningssed.html

Swedish School Inspectorate. (2010). Kvalitet i fritidshem. [Quality in the school-age educare.] Rapport 2010:3. Skolinspektionen. https://skolinspektionen.se/globalassets/02-beslut-rapporter-stat/granskningsrapporter/tkg/2010/fritidshem/rapportkvalitet-fritidshem.pdf

Swedish School Inspectorate. (2018). Undervisning i fritidshemmet inom områdena språk och kommunikation samt natur och samhälle. [Teaching in the school-age educare in areas of language and communication as well as nature and society.] Skolinspektionen. https://www.skolinspektionen.se/beslut-rapporter-statistik/publikationer/kvalitetsgranskning/2018/undervisning-ifritidshemmet/ 
Evaluating the practice in Swedish school-age educare...

Thornton, P.H. \& Ocasio, W. (1999). Institutional logics and the historical contingency of power in organizations: Executive succession in the higher education publishing industry 1958-1999. American Journal of Sociology, 105(3), 801-843. https://doi.org/10.1086/210361

Thornton, P.H. (2004). Markets from culture: Institutional logics and organizational decisions in higher education publishing. Stanford University Press.

Thornton, P.H., Ocasio, W., \& Lounsbury, M. (2012). The institutional logics perspective: A new approach to culture, structure and process. Oxford University Press.

Wahlström, N., \& Sundberg, D. (2015). En teoribaserad utvärdering av läroplanen Lgr 11. [A theory based evaluation of the curricula Lgr11.] IFAU-rapport 2015:7. IFAU. https://www.ifau.se/Forskning/Publikationer/Rapporter/2015/En-teoribaseradutvardering-av-laroplanen-Lgr-11/ 